Research article

\title{
Effects of enclosures and rangeland ecological sites on chemical composition of herbaceous species in south central Ethiopia
}

\author{
M. Gudisa ${ }^{1}$, A. Angassa ${ }^{2 *}$, A. Abebe ${ }^{1}$, K. Feyisa ${ }^{3}$ and A. Mengistu ${ }^{4}$ \\ ${ }^{1}$ School of Animal and Range Sciences, College of Agriculture, Hawassa University \\ ${ }^{2}$ Botswana University of Agriculture and Natural Resources, Department of Range and Forest Resources \\ ${ }^{3}$ School of Plant and Horticultural Sciences, College of Agriculture, Hawassa University \\ ${ }^{4}$ Forage and Rangeland Scientist, Urael Branch, P.O. Box 62291, Addis Ababa, Ethiopia
}

\section{ARTICLE INFORMATION}

\section{Keywords}

Nutritional quality

Grazing management

Altitude

Dry matter

Crude protein

\section{Article History:}

Submission date: 17 Apr. 2019

Revised: $\quad 22$ Jan. 2020

Accepted: $\quad 25$ Jan. 2020

Available online: 04 Apr. 2020

https://bojaas.buan.ac.bw

\section{Corresponding Author:}

*A Angassa

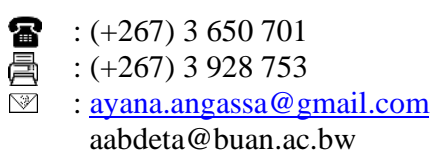

Abstract: This study was conducted in Adami-Tullu Jido-Kombolcha and Arsi Negelle districts, south central Ethiopia. The objectives of the study were to evaluate the interactive effects of grazing management systems and rangeland sites on dry-matter production and chemical composition of herbaceous plants in south central Ethiopia. Data were analyzed using GLM procedure in SPSS 16.0 version, which was used for mean comparisons using post-hoc t-test that can be employed to compare mean differences for enclosure and open-grazed areas. To test the effects of management systems and altitudinal variation on drymatter production and chemical composition of herbaceous species, mixed model analysis was employed using sample site as a random variable while grazing management systems and altitude were fixed variables. A total of 28 herbaceous species were identified. Of the identified herbaceous species, 20 species were grasses, 2 species were legumes while 6 species were forbs. Among the recorded grass species, some of them were highly desirable, while others were in the categories of intermediate in terms of desirability for grazing and less desirable. We identified the dominant and common grass species that included: Arstida adscensionis, Cenchrus ciliarus, Chloris gayana, Chloris roxburghiana, Bothriochloa insculpta, Eragrostis papposa, Heteropogon contorus, Panicum maximum, Indigofer spinosa, Tephrosia pumila, Sporobolus pyrmidalis, Themeda triandra, B. nigropedata, Ocimum basilicum, Amaranthus dubis, Tribulos terrestris and Achyrantes aspera. The chemical composition of herbaceous plants were analyzed for DM, CP, NDF, ADF, ADL and Ash comparing two grazing management systems and three rangeland sites as patch mosaic units. The results of the present analysis showed that the average CP content in the open-grazed areas was significantly $(P<0.05)$ higher than that of the enclosed areas. The upper and middle rangeland sites displayed a significantly $(P<0.05)$ higher CP content for the opengrazed areas than the enclosure management across the study areas. The present findings indicated that the DM, NDF, ADF, ADL and Ash contents of herbaceous species was significantly $(P<0.05)$ lower in the open-grazed areas than in the enclosure management.

\section{Introduction}

Knowledge of the nutritional quality of herbaceous plant communities is critical as native forage species constitute the major portion of feed for grazing animals (Teka et al., 2012). Natural grazing lands, dominated by herbaceous plant species, are major sources of feed for grazing animals (Melak et al., 2019). According to Beever et al. (2000), the nutrient content and voluntary feed intake of grazing animals are usually indicators of the feeding value of native grasses. On the other hand, management of grazing 
lands for sustainable yield and quality product requires an understanding of how grazing management systems and site factors within the rangeland may influence the nutritional quality of herbaceous species (Teka et al., 2012). Changes in microclimate in terms of rangeland sites and grazing management practices can have a profound effect on responses of herbaceous species in terms of dominance (Angassa, 2014) and nutritional quality (Teka et al., 2012). Thus, information on the nutritional quality of native grass species is key for enhancing sustainable livestock development (Teka et al., 2012).

Laboratory evaluation of herbaceous forage samples is a necessary step to provide the required information to update rangeland management and forage improvement programs for sustainable development in the livestock sector. Accurate information on the nutritional quality of native herbaceous forages can help extension workers to guide farmers in the promotion and utilization of promising indigenous herbaceous forage species in the study areas. Consequently, the chemical composition of a particular herbaceous plant species analysis may possibly include evaluation of the drymatter (DM), crude protein (CP), acid detergent fiber (ADF), neutral detergent fiber (NDF), acid detergent lignin (ADL) and Ash content (Van Soest et al., 1991).

Analysis of the DM of herbaceous forage is important because feed nutrients as a rule reported on DM basis to eliminate the dilution effect of moisture to allow more direct estimation of stocking rates to adjust the number of livestock to the available forage during a particular season of a year. The potential of rangeland for livestock production is typically determined by the quality and palatability of the forage provided in terms of adequate supply of the required nutrients (i.e., energy, protein, minerals and vitamins) for animals (Asaadi and Yazdi, 2011). A readily available information about the nutrient content of native grasses is essential to support management and decision making regarding the quality of herbaceous forages to sustain satisfactory growth and quality products from the livestock sector (Ganskopp and Bohnert, 2001). This enables managers and livestock producers to use native forage resources at the proper stage of maturity for maximum benefits (Arzani et al., 2006). The focus of this paper is to consider the effects of enclosure management and rangeland sites on the chemical composition and nutritional values of herbaceous species. We analyzed the nutritional value of key indigenous herbaceous species in relation to grazing management systems and rangeland sites in south central Ethiopia. The objectives of this study were: (1) To evaluate the effects of grazing management systems on the chemical composition of herbaceous plants; (2) To evaluate the effects of rangeland sites/landscape patches on chemical composition of herbaceous plants in the study areas.

\section{Materials and methods}

\section{Description of the study area}

The present study was carried out in Adami-Tullu Jido-Kombolcha and Arsi-Negelle districts of southcentral Ethiopia. Adami-Tullu Jido-Kombolcha is located between $38^{0} 37^{\prime} 12^{\prime \prime}-38^{\circ} 40^{\prime} 4{ }^{\prime \prime} \mathrm{E}$ and $7^{0} 45^{\prime} 36^{\prime \prime}-7^{0} 49^{\prime} 48^{\prime \prime} \mathrm{N}$ while Arsi-Negelle is located $38^{0} 38^{\prime} 24^{\prime \prime}-38^{\circ} 42^{\prime} 36^{\prime \prime} \mathrm{E}$ and $7^{0} 26^{\prime} 24^{\prime \prime}-7^{0} 34^{\prime} 12^{\prime}{ }^{\prime} \mathrm{N}$. The average annual rainfall distribution and temperature are in the ranges of $700 \mathrm{~mm}$ to $900 \mathrm{~mm}$ and $23^{\circ} \mathrm{C}-26^{\circ} \mathrm{C}$, respectively in Adami-Tullu JidoKombolcha (OESPO, 2003). In Arsi-Negelle district, the annual rainfall and temperature are within the range of $900 \mathrm{~mm}$ to $1100 \mathrm{~mm}$ and $28^{\circ} \mathrm{C}$ to $30^{\circ} \mathrm{C}$, respectively (Arsi-Negelle Agricultural Office). The soil types of both districts are mostly sandy and clay soils within an altitude range of $1500 \mathrm{~m}-2300 \mathrm{~m}$ in Adami-Tulu Jido-Kombolcha district (Adami-Tulu Jido-Kombolcha district Agricultural Office).

\section{Site selection}

Before the actual field study, observations were made throughout the study Kebeles (i.e., the lower Adamistrative structure in Ethiopia) for a general overview of the nature and distribution of enclosures and open-grazed areas for proper site selection. The study Kebeles were stratified into three rangeland sites/microclimates for proper stratification of the experimental sites based on landscape patch mosaics as it may affect key plant species and forage quality. The landscape patch mosaics ranges were categorized into bottomland site $(1550-1560 \mathrm{~m})$, middle landscape units (1560-1575 m) and upper rangeland sites $(1578-1595 \mathrm{~m})$ to accommodate variation in terms of herbaceous species composition within rangeland sites.

\section{Sampling procedure}

Systematic stratified random sampling technique" was used for sampling method (ILCA, 1990). A total of 108 herbaceous plant samples were collected across the study sites with 36 samples per location (12 samples per rangeland site within each location). Herbaceous plant species were randomly sampled using $1 \mathrm{~m} \times 1 \mathrm{~m}$ quadrat (Table 1). At each sample site, herbaceous plants were identified, sorted into their respective species and samples were harvested at the ground level in $1 \mathrm{~m} \times 1 \mathrm{~m}$ quadrat along the established transects at an interval of $30 \mathrm{~m}$. Then, samples were weighed using a digital sensitive balance, then samples stored in properly labelled 


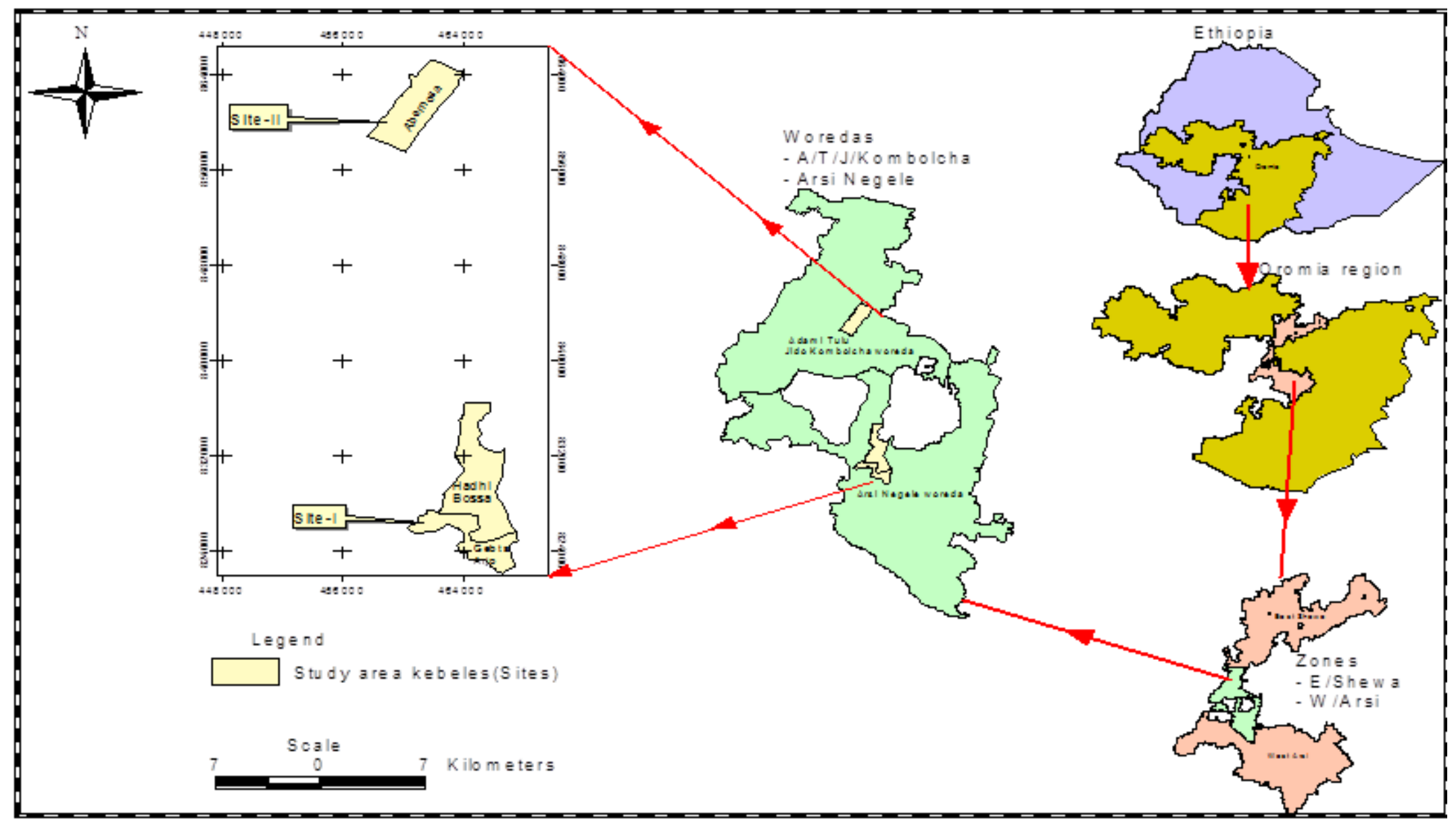

Figure 1: Map of the Study sites in Adami-Tullu Jido-Kombolcha and Arsi-Negelle districts, Ethiopia. 
Table 1: Experimental design used for herbaceous sample collection in Adami-Tullu Jido-Kombolcha and ArsiNegelle districts.

\begin{tabular}{llllll}
\hline \multirow{2}{*}{ Grazing type } & \multicolumn{6}{l}{ Location of rangeland Site (Kebeles) } \\
\cline { 2 - 6 } & Abernosa & Hadha-Bossa & Gubeta-Arjo & Sub-total & Quadrat \\
\hline Enclosed areas & 1 & 1 & 1 & 3 & 54 \\
Open-grazed areas & 1 & 1 & 1 & 3 & 54 \\
Total & 2 & 2 & 2 & 6 & 108 \\
\hline
\end{tabular}

paper bag and fastened at the top. Samples were then kept under shade until sample collection for the day was completed. Consequently, samples were air dried till the end of data collection. The DM of herbaceous samples was determined at $65^{\circ} \mathrm{C}$ for 48 hours at Hawassa University, College of Agriculture in the Animal Nutrition Laboratory.

\section{Analysis of herbaceous plants for chemical composition and dry matter}

Oven-dried samples were ground in a Willey mill to pass through $1 \mathrm{~mm}$ sieve for the determination of chemical composition of herbaceous plants. Accordingly, the DM and ash contents were analyzed following the method of AOAC (2000). Nitrogen was determined using the micro-Kjeldahl method (AOAC, 2000) and crude protein (CP) was calculated as $\mathrm{N} \times$ 6.25. Neutral detergent fiber (NDF), acid detergent fiber (ADF) and acid detergent lignin (ADL) were analyzed according to Van Soest and Robertoson (1985).

\section{Data analysis}

The DM, CP, NDF, ADF and ADL of herbaceous plants were considered as numerical response variables. Herbaceous species composition was analyzed using descriptive statistics. T-test was employed to compare mean differences between enclosures management and open-grazed areas. Mixed model analysis was used to test the effects of management (enclosures versus open-grazing areas) and rangeland sites on DM production and chemical composition of herbaceous vegetation as site is random variable while management and rangeland sites were fixed variables.

\section{Results}

\section{Effects of management on chemical composition of herbaceous species}

Table 2 presents the chemical composition of herbaceous plants in the study areas as affected by grazing management systems (enclosures vs. opengrazed areas). The DM production of herbaceous plant species did not show any significant $(P>0.05)$ difference between enclosure and the open-grazed areas at Gubeta-Arjo Kebele. However, the DM of herbaceous plants showed a significant $(P<0.05)$ difference between the two management systems (enclosures vs. open-grazed areas) at Hadha-Bossa and Abernosa Kebeles.

The ash contents of herbaceous plants were significantly $(P<0.05)$ higher in enclosures than the open-grazed areas across the study Kebeles. In contrast, the $\mathrm{CP}$ content of herbaceous plants was significantly $(P<0.05)$ higher in the open-grazed areas than in the enclosures management system. The chemical constituents (i.e., NDF, ADF and ADL) of herbaceous plants were significantly $(P<0.05)$ higher in enclosures than in the open-grazed areas.

Table 2: Chemical composition (Mean $\pm \mathrm{SE}$ ) of herbaceous species at different site by grazing management (enclosure vs. open-grazed) in South central Rift Valley of Ethiopia.

\begin{tabular}{lllllll}
\hline \multirow{2}{*}{ Parameter } & Abernosa & \multicolumn{3}{c}{ Hadha-Bossa } & Gubeta-Arjo \\
\cline { 2 - 7 } & Enclosure & Open-grazed & Enclosure & Open-grazed & Enclosure & Open-grazed \\
\hline DM $(\%)$ & $91.35 \pm 0.74^{\mathrm{a}}$ & $88.91 \pm 0.74^{\mathrm{b}}$ & $93.28 \pm 0.74^{\mathrm{a}}$ & $92.45 \pm 0.74^{\mathrm{b}}$ & $93.65 \pm 0.74^{\mathrm{a}}$ & $92.92 \pm 0.74^{\mathrm{a}}$ \\
Ash & $11.1 \pm 0.77^{\mathrm{a}}$ & $7.88 \pm 0.77^{\mathrm{b}}$ & $7.51 \pm 0.77^{\mathrm{b}}$ & $6.95 \pm 0.77^{\mathrm{a}}$ & $7.31 \pm 0.77^{\mathrm{b}}$ & $5.18 \pm 0.77^{\mathrm{a}}$ \\
NDF & $59.8 \pm 0.76^{\mathrm{a}}$ & $57.58 \pm 0.76^{\mathrm{b}}$ & $63.01 \pm 0.76^{\mathrm{a}}$ & $61.21 \pm 0.76^{\mathrm{b}}$ & $67.77 \pm 0.76^{\mathrm{a}}$ & $52.97 \pm 0.76^{\mathrm{b}}$ \\
ADF & $32.5 \pm 14.72^{\mathrm{a}}$ & $30.7 \pm 14.72^{\mathrm{b}}$ & $39.97 \pm 14.72^{\mathrm{a}}$ & $33.5 \pm 14.72^{\mathrm{b}}$ & $41.31 \pm 14.72^{\mathrm{a}}$ & $29.15 \pm 14.72^{\mathrm{b}}$ \\
ADL & $8.63 \pm 0.49^{\mathrm{a}}$ & $7.37 \pm 0.49^{\mathrm{b}}$ & $9.00 \pm 0.49^{\mathrm{a}}$ & $8.38 \pm 0.49^{\mathrm{b}}$ & $8.20 \pm 0.49^{\mathrm{a}}$ & $7.80 \pm 0.49^{\mathrm{b}}$ \\
CP & $10.25 \pm 0.41^{\mathrm{b}}$ & $11.59 \pm 0.41^{\mathrm{a}}$ & $9.71 \pm 0.41^{\mathrm{b}}$ & $10.76 \pm 0.41^{\mathrm{a}}$ & $7.31 \pm 0.41^{\mathrm{b}}$ & $14.60 \pm 0.41^{\mathrm{a}}$ \\
\hline
\end{tabular}

Mean in the same row for each parameter with different superscripts are significantly different $(\mathrm{P}<0.05)$.

Note: DM, dry matter; Ash, CP, crude protein; NDF, neutral detergent fiber; ADF, acid detergent fiber; ADL, acid detergent lignin. 
Table 3: Chemical composition (Mean \pm SE) of herbaceous species at different altitude by site and grazing management systems (enclosure vs. open-grazed) in South Central Rift valley of Ethiopia.

\begin{tabular}{|c|c|c|c|c|c|c|c|}
\hline \multirow{3}{*}{ Site } & \multirow{3}{*}{ Parameter } & \multicolumn{6}{|l|}{ Altitude } \\
\hline & & \multicolumn{2}{|c|}{$\begin{array}{l}\text { Upper range site ( } 1578 \mathrm{~m} \text { - } \\
1595 \mathrm{~m})\end{array}$} & \multicolumn{2}{|c|}{$\begin{array}{l}\text { Middle range site }(1560 \mathrm{~m} \text { - } \\
1575 \mathrm{~m})\end{array}$} & \multicolumn{2}{|c|}{$\begin{array}{l}\text { Lower range site }(1550 \mathrm{~m} \text { - } \\
1558 \mathrm{~m})\end{array}$} \\
\hline & & Enclosure & Open-grazed & Enclosure & Open- grazed & Enclosure & Open-grazed \\
\hline \multirow[t]{6}{*}{ Abernosa } & $\mathrm{DM}(\%)$ & $92.91 \pm 4.6^{\mathrm{a}}$ & $87.87 \pm 4.6^{\mathrm{b}}$ & $91.67 \pm 4.6^{\mathrm{a}}$ & $89.81 \pm 4.6^{\mathrm{b}}$ & $90.01 \pm 4.6^{\mathrm{a}}$ & $88.24 \pm 4.6^{\mathrm{b}}$ \\
\hline & Ash & $11.09 \pm 1.35^{\mathrm{a}}$ & $7.3 \pm 1.35^{\mathrm{b}}$ & $9.05 \pm 1.35^{\mathrm{a}}$ & $7.32 \pm 1.35^{\mathrm{b}}$ & $8.14 \pm 1.35^{\mathrm{a}}$ & $7.04 \pm 1.35^{\mathrm{b}}$ \\
\hline & $\mathrm{NDF}$ & $60.32 \pm 1.32^{\mathrm{a}}$ & $57.04 \pm 1.32^{\mathrm{b}}$ & $59.32 \pm 1.32^{\mathrm{a}}$ & $53.32 \pm 1.32^{\mathrm{b}}$ & $59.232 \pm 1.3^{\mathrm{a}}$ & $56.12 \pm 1.32^{\mathrm{b}}$ \\
\hline & $\mathrm{ADF}$ & $32.54 \pm 3.27^{\mathrm{a}}$ & $29.95 \pm 3.27^{\mathrm{b}}$ & $31.49 \pm 3.27^{\mathrm{a}}$ & $30.59 \pm 3.27^{\mathrm{b}}$ & $29.49 \pm 3.27^{\mathrm{a}}$ & $27.59 \pm 3.27^{\mathrm{b}}$ \\
\hline & ADL & $8.22 \pm 0.41^{\mathrm{a}}$ & $7.56 \pm 0.41^{b}$ & $7.98 \pm 0.41^{\mathrm{a}}$ & $6.96 \pm 0.41^{\mathrm{b}}$ & $7.68 \pm 0.41^{\mathrm{a}}$ & $6.26 \pm 0.41^{b}$ \\
\hline & $\mathrm{CP}$ & $10.63 \pm 0.72^{b}$ & $11.20 \pm 0.72^{\mathrm{a}}$ & $9.28 \pm 0.72^{b}$ & $10.88 \pm 0.72^{\mathrm{a}}$ & $8.28 \pm 0.72^{b}$ & $10.23 \pm 0.72^{\mathrm{a}}$ \\
\hline \multirow[t]{6}{*}{$\begin{array}{l}\text { Hadha- } \\
\text { Bossa }\end{array}$} & $\mathrm{DM}(\%)$ & $94.47 \pm 4.6^{\mathrm{a}}$ & $92.01 \pm 4.6^{\mathrm{b}}$ & $93.26 \pm 4.6^{\mathrm{a}}$ & $92.33 \pm 4.6^{\mathrm{b}}$ & $93.12 \pm 4.6^{\mathrm{a}}$ & $91.02 \pm 4.6^{\mathrm{b}}$ \\
\hline & Ash & $8.78 \pm 1.35^{\mathrm{a}}$ & $6.69 \pm 1.35^{\mathrm{b}}$ & $7.70 \pm 1.35^{\mathrm{a}}$ & $6.53 \pm 1.35^{\mathrm{b}}$ & $7.40 \pm 1.35^{\mathrm{a}}$ & $5.31 \pm 1.35^{\mathrm{b}}$ \\
\hline & $\mathrm{NDF}$ & $61.55 \pm 1.32^{\mathrm{a}}$ & $59.81 \pm 1.32^{\mathrm{b}}$ & $60.02 \pm 1.32^{\mathrm{a}}$ & $58.08 \pm 1.32^{\mathrm{b}}$ & $57.46 \pm 1.32^{\mathrm{a}}$ & $55.75 \pm 1.32^{\mathrm{b}}$ \\
\hline & $\mathrm{ADF}$ & $40.76 \pm 3.27^{\mathrm{a}}$ & $33.85 \pm 3.27^{\mathrm{b}}$ & $39.39 \pm 3.27^{\mathrm{a}}$ & $32.57 \pm 3.27^{\mathrm{b}}$ & $38.29 \pm 3.27^{\mathrm{a}}$ & $30.09 \pm 3.27^{\mathrm{b}}$ \\
\hline & $\mathrm{ADL}$ & $9.34 \pm 0.41^{\mathrm{a}}$ & $8.92 \pm 0.41^{\mathrm{b}}$ & $9.01 \pm 0.41^{\mathrm{a}}$ & $8.52 \pm 0.41^{\mathrm{b}}$ & $8.09 \pm 0.41^{\mathrm{a}}$ & $7.21 \pm 0.41 .3^{\mathrm{b}}$ \\
\hline & $\mathrm{CP}$ & $10.60 \pm 0.72^{b}$ & $12.46 \pm 0.72^{\mathrm{a}}$ & $9.93 \pm 0.72^{b}$ & $10.95 \pm 0.72^{\mathrm{a}}$ & $9.75 \pm 0.72^{b}$ & $10.76 \pm 0.72^{\mathrm{a}}$ \\
\hline \multirow[t]{6}{*}{$\begin{array}{l}\text { Gubeta- } \\
\text { Arjo }\end{array}$} & $\mathrm{DM}(\%)$ & $94.58 \pm 4.5^{\mathrm{a}}$ & $92.56 \pm 4.6^{\mathrm{b}}$ & $93.38 \pm 4.6^{\mathrm{a}}$ & $91.94 \pm 4.6^{\mathrm{b}}$ & $93.0 \pm 4.6^{\mathrm{a}}$ & $90.28 \pm 4.6^{\mathrm{b}}$ \\
\hline & Ash & $7.41 \pm 1.35^{\mathrm{a}}$ & $5.28 \pm 1.35^{\mathrm{b}}$ & $6.27 \pm 1.35^{\mathrm{a}}$ & $5.13 \pm 1.35^{\mathrm{b}}$ & $5.26 \pm 1.35^{\mathrm{a}}$ & $4.16 \pm 1.35^{\mathrm{b}}$ \\
\hline & $\mathrm{NDF}$ & $68.25 \pm 132^{\mathrm{a}}$ & $53.16 \pm 1.32^{\mathrm{b}}$ & $67.19 \pm 1.32^{\mathrm{a}}$ & $52.07 \pm 1.32^{\mathrm{b}}$ & $61.88 \pm 1.32^{\mathrm{a}}$ & $50.70 \pm 1.32^{\mathrm{b}}$ \\
\hline & $\mathrm{ADF}$ & $41.47 \pm 3.27^{\mathrm{a}}$ & $30.52 \pm 3.27^{\mathrm{b}}$ & $40.03 \pm 3.27^{\mathrm{a}}$ & $29.57 \pm 3.27^{b}$ & $39.43 \pm 3.27^{\mathrm{a}}$ & $28.37 \pm 3.27^{b}$ \\
\hline & $\mathrm{ADL}$ & $8.33 \pm 0.41^{\mathrm{a}}$ & $7.99 \pm 0.41^{\mathrm{b}}$ & $8.19 \pm 0.41^{\mathrm{a}}$ & $6.88 \pm 0.41^{\mathrm{b}}$ & $7.08 \pm 0.41^{\mathrm{a}}$ & $6.56 \pm 0.41^{\mathrm{b}}$ \\
\hline & $\mathrm{CP}$ & $7.36 \pm 0.72^{\mathrm{b}}$ & $15.06 \pm 0.72^{\mathrm{a}}$ & $7.22 \pm 0.72^{\mathrm{b}}$ & $14.57 \pm 0.72^{\mathrm{a}}$ & $6.29 \pm 0.72^{\mathrm{b}}$ & $11.19 \pm 0.72^{\mathrm{a}}$ \\
\hline
\end{tabular}

Note: DM, dry matter; Ash, CP, crude protein; NDF, neutral detergent fiber; ADF, acid detergent fiber; ADL, acid detergent lignin.

Mean in the same row for each parameter with different superscripts are significantly different $(\mathrm{P}<0.05)$.

Effects of management systems on chemical composition of herbaceous species by rangeland site

The chemical composition of herbaceous plant species in the bottomland microclimate is presented in Table 3. The DM and ash contents of herbaceous plants in the bottomland microclimate were significantly $(P<0.05)$ varied between enclosures management and the open-grazed areas. Generally, the DM of herbaceous plants in the bottomland microclimate was significantly $(P<0.05)$ higher in enclosures than in the open-grazed areas at HadhaBossa and Gubeta-Arjo Kebeles. Similarly, the ash contents of herbaceous plants in the bottomland microclimate were significantly $(P<0.05)$ higher in enclosures than in the open-grazed areas at Abernosa and Hadha- Bossa Kebeles.

The overall CP contents of herbaceous plants in the bottomland microclimate was significantly $(P<0.05)$ lower in enclosures than in the open-grazed areas. The CP content of herbaceous plant in the bottomland microclimate was significantly $(P<0.05)$ higher in the open-grazed areas than in the enclosures at Gubeta-Arjo kebele, while the CP content of herbaceous plants at Hadha-Bossa and Abernosa Kebeles within the bottomland microclimate was significantly $(\mathrm{P}<0.05)$ lower within enclosure than in the open-grazed areas. The chemical constituents (i.e., NDF, ADF, and AD) of herbaceous plants in the bottomland altitude was significantly $(P<0.05)$ higher in the enclosure's management than in the open-grazed areas.

Table 3 presents the chemical composition of herbaceous plants in the middle rangeland sites microclimate. The DM yield of herbaceous plants was significantly $(P<0.05)$ differed between the enclosure's management and open-grazed areas in the relatively middle rangeland sites microclimate of the study Kebeles. The results of the current study showed that the DM and ash contents of herbaceous plants in the middle rangeland sites microclimate were significantly $(P<0.05)$ higher in the enclosures 
management than in the open-grazed areas.

The CP content of herbaceous plants was significantly $(P<0.05)$ lower in the enclosure's management than in the open-grazed areas in all the study Kebeles. The CP content of herbaceous plants in the medium altitude was significantly $(P<0.05)$ higher in the open-grazed areas than the enclosures management at Gubeta-Arjo Kebele. The NDF, ADF and ADL contents of herbaceous plants was significantly $(P<0.05)$ higher in the enclosures management than in the open-grazed areas. The NDF content of forage samples in the middle rangeland sites microclimate was significantly $(P<0.05)$ higher in the enclosures management than in the opengrazed areas at Gubeta-Arjo and Abernosa Kebeles.

The chemical composition of herbaceous plants in the upper rangeland site microclimate is presented in Table 3. The DM contents of herbaceous plants in the upper rangeland site was significantly $(P<0.05)$ higher in the enclosures management than in the open-grazed areas at Gubeta-Arjo and Hadha-Bossa Kebeles. The ash content of herbaceous plants in the upper rangeland site microclimate was significantly $(P<0.05)$ higher in the enclosures management than in the open-grazed areas at Abernosa Kebele.

The CP content of herbaceous plants in the upper rangeland site was significantly $(P<0.05)$ lower in the enclosures management than in the open-grazed areas. The CP content of herbaceous plants in the upper rangeland site was also significantly $(\mathrm{P}<0.05)$ higher in open-grazed areas than in the enclosures management at Gubeta-Arjo Kebele. The NDF, ADF and ADL content of herbaceous plants in the upper rangeland site were significantly $(P<0.05)$ higher in enclosures than in the open-grazed areas.

\section{Discussion}

Effects of management on chemical composition of herbaceous species

The results of the present finding indicate that the potentials of rangeland sites significantly influenced the nutritive value of herbaceous species between the two grazing management systems. This is in agreement with the works of Teka et al. (2012) and Mittal et al. (2012), suggesting that rangeland sites greatly influence the nutritional quality of grass species in southern Ethiopia and in the hill area of India, respectively. The results of the current study showed that differences in land use management can greatly influence the nutritive value of herbaceous plants in arid and semi-arid environments. The possible explanations for the variation among sites may be due to differences in soil nutrient status and the intensity of grazing, where most palatable species may possibly be affected by extended grazing times.
There was a higher content of $\mathrm{CP}$ in the open-grazed areas than enclosure areas. The possible explanation for high CP content in the open-grazed areas of rangeland sites may be attributed to the frequency of old forage removal by grazers, rejuvenation of new growth and deposition of manure and urine from grazers that might help to improve soil fertility and plant nutrient content (Teka et al., 2012).

Furthermore, the results of the current study indicate that enclosures have accumulated higher NDF, ADF and ADL contents than open-grazed areas across the study sites. The possible reasons for high fibers content in the studied herbaceous plant samples could be due to lack of timely harvest and utilization at proper stage of maturity where the structural fibers get more accumulated as the age of plant maturity advances. This is in agreement with the reports of others scholars (Shankute et al., 2011; Teka et al., 2012). The low accumulation of CP and increased level of fibers in plant samples are most likely better indicators of the low quality of inadequately managed rangelands. Overall, the nutritive values of herbaceous species were significantly varied among rangeland sites and might influence the grazing values of forage plants by animals.

\section{Chemical composition of herbaceous species in bottomland microclimate $(1550 \mathrm{~m}-1560 \mathrm{~m})$}

The results of the present study showed a significantly higher dry-matter content of herbaceous species in enclosures than in the open-grazed areas in the upper and middle rangeland sites at Hadha-Bossa and Gubeta-Arjo Kebeles. This might be because of variations in the physiology and morphology/anatomy of individual herbaceous plant species and dry-matter yield may also increase with an increase in the growth, development and maturity of the forage plants and harvest time. This is in agreement with the work of other researchers (Ahmed, 2006; Sisay, 2006) that suggested that the dry-matter production of forage plants is affected by site differences are influenced by soil factors and microclimate. The ash contents of the present findings were significantly higher in the enclosures management than in the open-grazed areas in the upper and middle rangeland sites than in the bottomland microclimate (rangeland sites).

The average ash contents of forage samples taken from the two grazing systems at different rangeland sites/microclimates, imply that the ash content of herbaceous forage species declined as stage of maturity in plants advances, which is also in agreement with the work of Yihalem (2004). Previous studies (Mahala et al., 2009; Sub-halakshmi et al., 2011) have shown that variations in rangeland sites/microclimate have had effect on the nutritive 
value of native herbaceous forage species. Similarly, Teka et al. (2012) have reported that the variation in the nutritive value of herbaceous species is influenced by site potential in terms of differences in soil and temperature conditions. Most grasses and tree leaves in arid and semi-arid environments are low in nutritive values, due to the high contents of lignin and relatively indigestible materials, which is also reported by Yihalem (2004).

The chemical components of herbaceous species such as NDF, ADF and ADL were significantly higher in enclosures than in the open-grazed areas. DM intake and digestibility of these forage species could be limited due to the high content of NDF. Generally, high NDF content in the present analysis is most likely attributed to the variability of rangeland sites/microclimate that in turn would limit the nutritional quality and DM intake, as well as digestibility. This agrees with the work of Alemu (1982) that suggested that herbaceous species utilization is greatly affected by NDF content of forage feeds. Overall, forage species with high NDF, $\mathrm{ADF}$ and ADL contents might have low nutritional value, reduced DM intake and digestibility. The findings suggest that the nutritive value of herbaceous species was greatly influenced by the type of plant species. We also confirmed that the CP content of most herbaceous plants in the open-grazed areas of upper and middle rangeland sites was significantly higher than that of enclosures most likely due to the fact that older grasses within enclosures are more lignified with increased structural constituents and low protein content, which is also in accordance with the report by Ammar (2004).

The findings further confirm that the dry-matter production across rangeland sites was above $90 \%$ in the enclosures management vs. in the open-grazed areas with the exception of open-grazed areas at Abernosa. This implies that exclusion of livestock grazing might encourage more accumulation of drymatter production under reduced grazing pressure with extended period of rest. On the other hand, less dry-matter accumulation in the open-grazed areas could be because of the influence of frequent grazing without rest. This is in agreement with the work of Haftay et al. (2013), who indicated the negative influence of livestock grazing on herbaceous production in open-grazed areas as compared to enclosures. Similarly, Tessema et al. (2010) has reported that the dry-matter production of grasses increases with an increase in growth period and stage of maturity.

The dry-matter content of herbaceous species was significantly higher in the enclosures management than in the open-grazed areas at the middle and upper rangelands sites than in the bottomland microclimate at Hadha-Bossa and Gubeta-Arjo Kebeles. The results displayed that the ash contents of the forage samples were significantly higher in the enclosures management than in the open-grazed areas of upper and middle rangeland sites. The probable explanation for the decline in ash content of herbaceous species in the open-grazed areas at the upper and middle rangeland sites is probably associated with the effect of accelerated erosion where soils are more exposed under increased slope and trampling effect (Yihalem, 2004).

The $\mathrm{CP}$ content of herbaceous plants in the study sites was significantly higher in the open-grazed areas than enclosures management. The probable explanation might be due to the contribution of grazing animals for the removal of old pasture and deposition of manure that helps to improve soil fertility and plant nutrient content as reported by Teka et al. (2012). Similarly, the results for NDF and $\mathrm{ADF}$ were higher in enclosures management than open-grazed areas across all rangeland sites. This is probably due to lack of proper management such as timely grazing and harvesting that further encourages more accumulation of fibers in the studied samples of herbaceous plants. This is also in line with the work of others (Teka et al., 2012; Shankute et al., 2011). The low accumulation of CP and increased level of fibers are also good indicators of the poor quality of forage plants. It seems that the chemical composition of herbaceous forage is more influenced by the stage of forage maturity than any other factors.

The study shows that the dry-matter production of herbaceous plants was higher in the enclosures management than in the open-grazed areas particularly in the upper and middle rangeland sites at Hadha-Bossa and Gubeta-Arjo Kebeles. Reduced grazing and increased stage of maturity of plants with longer period before harvesting might be a major reason for more accumulation of herbaceous biomass production within enclosures. Other researchers (Tessema et al., 2010; Teka et al., 2012) have also reported a similar case in terms of dry matter production.

The ash contents were significantly higher in enclosures management than in the open-grazed areas at the upper and middle rangeland sites at Abernosa and Hadha-Bossa Kebeles. This is most likely due to the accumulation of old herbaceous species, leaching of some minerals due to weather conditions and exposure of the soil to erosion in terms of continuous disturbance. The $\mathrm{CP}$ contents of herbaceous plants in the study sites were significantly higher in open-grazed areas than enclosures in the study sites across the three altitude ranges. The probable explanation may be due to removal of old pasture by animal in the open-grazed 
areas that helps to encourage the regeneration of new herbaceous plant species growth, which is also in agreement with the work of Teka et al. (2012).

Likewise, the extent of NDF, ADF and ADL in enclosures along the three altitude ranges were high in the study districts. Most grasses and tree leaves in arid and semi-arid environments are low in their nutritive values mainly because of the high contents of lignin and relatively indigestible cellulose and hemi-cellulose materials.

\section{Conclusion}

The analysis leads to the following conclusions. The results showed that the average $\mathrm{CP}$ content of herbaceous plant species in the open-grazed areas was significantly higher than that of enclosure areas. The upper and middle altitude ecological sites displayed a significantly higher $\mathrm{CP}$ content for the open-grazed areas than the enclosures across the study areas. The DM, NDF, ADF, ADL and Ash contents of herbaceous species were significantly lower in the open-grazed areas than in the enclosures. The chemical composition of herbaceous plants at different rangeland ecological sites was greatly differed. This is an important finding in the understanding of the effects of grazing management and rangeland ecological sites on the chemical composition of herbaceous plants to enhance livestock productivity. Despite the limitations, the results are helpful in light of grassland management and site specific feed quality improvement. Although these findings provide a useful approach in identifying the potential effects of grazing management and rangeland ecological sites on the nutritional quality of herbaceous species, future research is needed to consider the potential effects of ecological sites more carefully both at local and regional levels.

\section{Acknowledgements}

The authors thank the local communities and officials in the study area for their support during the data collection. We would also thank Mr. Bedru Roba, Adami Tulu Research Center for his assistance during data collection in the identification of herbaceous species in the field.

\section{References}

Abule, E. (2003). Rangeland evaluation in relation to pastoralists' perceptions in the middle awash valley of Ethiopia. A Ph.D Thesis Presented to the University of the Free State, Bloemfontein, and South Africa. $297 \mathrm{pp}$.

Admasu, T. (2006). Pastoralists' perceptions on range-livestock management practices and rangeland assessment in Hamer and Benna-
Tsemay districts of South Omo Zone. M.Sc Thesis Presented to the School of Graduate Studies of Alemaya University, Ethiopia. 159 pp.

Ahmed, B. (2003). Soil condition and vegetation cover in human impacted rangelands of Jijiga, Somali Regional State. M.Sc Thesis Presented to the School of Graduate Studies of Alemaya University. 108 pp.

Alemayehu, M. (2004). Rangeland: Biodiversity Concepts, Approaches and the way forward. Addis Ababa University, Faculty of Science, Addis Ababa, Ethiopia, 80 pp.

Alemayehu, M. (2005). Rangelands: Biodiversity Conservation and Management and Inventory and Monitoring. Addis Ababa University, Faculty of Science, Addis Ababa, Ethiopia.103 pp.

Alemu T. (1982). Grass land composition and current feeding systems in Nekemite Awraja. M.Sc Thesis Presented to the School of Graduate Studies of Addis Ababa University, Ethiopia. 92 pp.

Amaha, K. (2006). Characterization of rangeland resources and dynamics of the pastoral Production system in the Somali region of Eastern Ethiopia. A Ph.D Thesis Presented to the University of the Free State, Bloemfontein, South Africa. 232p.

Ammar H., López S., González J.S., Ranilla M.J. (2004). Seasonal variations in the chemical composition and in vitro digestibility of some Spanish leguminous shrub species. Journal of Animal and Feed Science 115: 327-340.

Angassa A. (1999). Range Condition and Traditional Grazing Management system in Borana. M.Sc Thesis. Alemaya University of Agriculture, Dire Dawa, Ethiopia.

Angassa A. (2014). Effects of grazing intensity and bush encroachment on herbaceous species and range land condition in southern Ethiopia. Land Degradation and Development 25: 438-451

Angassa A. and Beyene F. (2003). Current range condition in southern Ethiopia in relation to traditional management strategies: The perceptions of Borana pastoralists. Tropical Grasslands 37(1): 53-59.

AOAC (Association of Official Analytical Chemists). (2000). Official methods of analysis (15th ed). Inc., Washington D.C., USA.

Arzani H., Mahdavi S. KH., Nikkhah A., Azarnivand H. (2006). Determination of Animal Unit weight and Animal Unit Requirement of Dalagh breed (Case study: Agh Ghala Region). Iranian Journal of Range and Desert Research 13 (3): 236-248.

Asaadi, A.M., Yazdi, A.K. (2011). Phenological 
stage effects on forage quality of four forbs species. Journal of Food Agriculture and Environment 9 (2): 380-384.

Baars R.M.T., Chileshe E.C. and Kalokoni D.M. (1997). Technical Note. Range Condition in high cattle density areas in the Western Province of Zambia. Journal of Tropical Grasslands 31: 565-573.

Beever D.E., Offer N. and Gill M. (2000). The feeding value of grass and grass products. In: A. Hopkins (Ed.), Grass, its Production and Utilization. Blackwell Science, Oxford, 440 pp.

Belaynesh D. (2006). Floristic composition and diversity of the vegetation, soil seed bank flora and condition of the rangelands of the Jijiga Zone, Somali Regional State, Ethiopia. MSc Thesis Presented to the School of Graduate Studies of Alemaya University, Ethiopia.144 pp.

Ganskopp D. and Bohnert D. (2001). Nutritional dynamics of seven northern Great Basin grasses. Journal of Range Management 54: 640-647.

ILCA (International Livestock Centre for Africa), (1990). Livestock Research Manual. ILCA, Addis Ababa, Ethiopia.

Melak Y., Angassa A and Abebe A. (2019). Aster Effects of grazing intensity to water source on grassland condition, yield and nutritional content of selected grass species in Northwest Ethiopia. Ecological Processes 8: 12. https://doi.org/10.1186/s13717-019-0162-z.

Mittal G.K., Sharma K.M., Maheshwari M.L. and Barsaul C.S. (2012). Chemical composition of some natural available fodder resources in Hill area of Chakrata (Utter Pradesh). Indian Journal of Animal Nutrition 5: 341-344.

Shankute B., Hassen A., Ebro A., Asefa T. and Amen N. (2011). Identification of potential untapped herbaceous flora in the mid rift valley of Ethiopia and their nutritive value. African Journal of Agricultural research 6 (17): 41534158.

Sisay A. (2006). Livestock production systems and available feed resources in different agroecologies of North Gondar Zone, Ethiopia. M.Sc. Thesis Presented to the School of Graduate Studies of Haramaya University, Ethiopia, 139 pp.

Teka H., Casper M.I., Angassa A., Hassen A. (2012). Effect of seasonal variation on the nutritional quality of key herbaceous species in semi-arid Areas of Borana, Ethiopia. Indian Journal of Animal Nutrition 29 (4): 324-33.

Teshome A. (2007). Traditional utilization practices and condition assessment of the rangelands in Rayitu district of Bale zone, Ethiopia. MSc Thesis Presented to the School of Graduate Studies of Haramaya University, Dire
Dawa, and Ethiopia.129 pp.

Tessema Z.K., Mihret J., Solomon M. (2010). Effect of defoliation frequency and cutting height on growth, dry-matter yield and nutritive value of Napier grass (Pennisetum purpureum (L.) Schumach). Grass and Forage Science 65: 421430.

Van Soest P.J., and Robertoson J.B. (1985). Analysis of forage and fibrous foods. A laboratory manual for Animal Science 613. Cornell University, USA.

Yihalem D. (2004). Assessment of Botanical Composition and Stage of Harvesting of Selected Natural Pasture for Optimum Utilization as Hay at Andassa Livestock Research Center, Northwestern Ethiopia. MSc. Thesis Presented to the School of Graduate Studies of Alemaya University Dire Dawa, Ethiopia. 69 pp. 